\title{
FEEDING OF GUITARFISH Rhinobatos percellens (WALBAUM, 1972) (ELASMOBRANCHII, RHINOBATIDAE), THE TARGET OF ARTISANAL FISHERY IN SOUTHERN BRAZIL
}

\author{
Hugo Bornatowski ${ }^{1,2, *}$, Maurício de Castro Robert ${ }^{1 * *}$ and Luciano Costa ${ }^{2 * * *}$ \\ ${ }^{1}$ Universidade Federal do Paraná - Programa de Pós-Graduação em Zoologia \\ (Caixa Postal 19020, 81531-980 Curitiba, PR, Brasil)
}

${ }^{2}$ Museu de História Natural Capão da Imbuia - Grupo de Pesquisa da Ictiofauna (GPIc) (Rua Prof. Benedito Conceição, 407, 82810-080 Curitiba, PR, Brasil)

*Corresponding author: anequim.bio@gmail.com

**mauriciorobert@bol.com.br

***tetragonisca@yahoo.com.br

\begin{abstract}
A B S T R A C T
Rhinobatos percellens is one of three species of Rhinobatidae found on Brazilian shores and is one of the most abundant species on the shallow continental shelf of Paraná and Santa Catarina States. Specimens caught by artisanal fishery between July/2001 and March/2003 by fishing communities located on the frontier between two southern Brazilian States (Paraná and Santa Catarina) had their stomach contents analyzed. According to the Alimentary Index (IAi), Decapoda (69\%) and Teleostei $(22 \%)$ were the main items consumed. Polychaeta, a common prey consumed by several benthonic fishes, was poorly represented in the feeding of $R$. percellens. This fact may be related to the availability of prey in the environment, or to the size of the guitarfish analyzed (ontogeny). Seasonal variance of main preys (with higher IAi) was observed: Dendrobranchiata and Pleocyemata displayed higher percentages in spring and autumn, Teleostei in the winter and Brachyura during the summer.
\end{abstract}

\section{RESUMO}

Rhinobatos percellens é uma das três espécies de Rhinobatidae encontrada na costa brasileira e uma das espécies de elasmobrânquio mais abundante na plataforma continental dos estados do Paraná e Santa Catarina. Indivíduos capturados pela pesca artesanal entre Julho/2001 e Março/2003 nas comunidades pesqueiras localizadas entre o Paraná e Santa Catarina tiveram seus conteúdos estomacais analisados. O Índice de Importância Alimentar (IAi) mostrou que as principais presas consumidas foram Decapoda (69\%) e Teleostei (22\%). Polychaeta, principal presa ingerida por várias espécies de peixes bentônicos foi pouco expressiva na alimentação de $R$. percellens. Essa diferença pode estar relacionada com a disponibilidade de presas no ambiente ou com o tamanho das raias analisadas (ontogenia). De acordo com análises sazonais, observou-se que os camarões Dendrobranchiata e Pleocyemata foram as principais presas consumidas durante a primavera e outono, Teleostei durante o inverno e Brachyura durante o verão.

Descriptors: Chondrichthyes, Diet, Seasonal variation, Paraná, Santa Catarina. Descritores: Chondrichthyes, Dieta, Variação sazonal, Paraná, Santa Catarina.

\section{INTRODUCTION}

Chondrichthyan fishes form a relatively small (approximately 1,115 described species) and evolutionarily conservative group that has functioned successfully in diverse ecosystems for over 400 million years (CAMHI et al.., 2009). Despite their evolutionary success, many species are increasingly threatened with extinction as a result of their low reproductive rates in the face of human activities, primarily overfishing (CAMHI et al., 2009; MUSICK, 2005). Most elasmobranchs are K-strategists and therefore exhibit slow growth rates, late sexual maturity, low fecundity and long life-spans (CAMHI et al., 2009; MUSICK, 2005). Because of these characteristics, sharks and their relatives have very low rates of population increase and limited potential to recover from overfishing (direct or indirect) and other threats, such as pollution and habitat destruction (CAMHI et al., 2009: COMPAGNO, 2005; MUSICK, 2005). 
The family Rhinobatidae is represented by four genera but only two occur on the Brazilian coast (MENEZES et al., 2003; COMPAGNO, 2005). The genus Zapteryx is represented by $Z$. brevirostris (Müller \& Henle, 1841), and the genus Rhinobatos, by $R$. percellens (Walbaum, 1792) and $R$. horkelii Müller \& Henle, 1841. In Brazil, Rhinobatos species are known as "raia-viola" or "cação-viola", and $Z$. brevirostris, as "viola-de-focinho-curto", "caçãobandolim" or "piçudinho" (VOOREN et al., 2005; COSTA; CHAVES, 2006). In Southern and Southeastern Brazil, the two species of Rhinobatos are more abundant in deeper waters, below $100 \mathrm{~m}$ (MARTINS; SCHWINGEL, 2003). Even though $R$. horkelli distribution comprises the area between the northeast of Brazil and the Mar del Plata, Argentina (LESSA, 1982), this species has not been recorded in studies conducted on the continental shelf of Paraná and northern Santa Catarina (COSTA; CHAVES, 2006). On the other hand, $R$. percellens is common in this region (CHAVES et al., 2003; COSTA; CHAVES, 2006; ROBERT, 2008).

Rhinobatos percellens is a viviparouslecithotrophic benthic ray, especially associated with sandy and muddy bottoms on the continental shelf between the Caribbean coast and northern Argentina (McEACHRAN; CARVALHO, 1999; MENEZES et al., 2003). This species is one of the most abundant elasmobranchs in artisanal fisheries in northern Santa Catarina and southern Paraná (CHAVES et al., 2003; COSTA; CHAVES, 2006). It has commercial value and is commercialized as "shark", although not directly targeted by local fisheries (COSTA; CHAVES, 2006).

Several species of batoid fishes are frequently caught by fisheries along the Brazilian coast, often considered bycatch (MABRAGAÑA; GILBERTO, 2007). The biological characteristics of elasmobranchs indicate that they are particularly sensitive to fishing pressure and overexploitation (HOENIG; GRUBER, 1990; MUSICK, 2005), and that fishing pressure could lead to changes in the structure and functioning of benthic and demersal communities (STEVENS et al., 2000).

In this context, studies on feeding are extremely important in order to clarify the ecological dynamics of species and their role in natural systems, since they are a fundamental tool for the conservation and assessment of fish stocks, as well as the analysis of the ecosystem as a whole (GULLAND, 1983; PAULY, 1984; CADDY; SHARP 1986; BLABER; BULMAN 1987; WOOTTON, 1990; POWER, 1997; WINEMILLER et al., 2008). Considering that feeding habits are usually altered during seasonal variations (GERKING, 1994) and seasonal changes in feeding are usually a consequence of the availability of food items (BRODEUR et al., 1987), the present study seeks to assess seasonal variations in the feeding ecology of $R$. percellens located on the frontier between two Southern Brazilian States (Paraná and Santa Catarina).

\section{Material and Methods}

Forty-nine landings, carried out by the artisanal fishing communities of Brejatuba (255' $\mathrm{S}$; $\left.48^{\circ} 33^{\prime} \mathrm{W}\right)$, in Guaratuba municipality (Paraná state), and Barra do Saí $\left(26^{\circ} 00^{\prime} \mathrm{S}\right.$; $\left.48^{\circ} 36^{\prime} \mathrm{W}\right)$, in Itapoá municipality (Santa Catarina state) (Fig. 1), were observed between July/2001 and March/2003. Considering all the fishing gear used, $R$. percellens was only observed in catches made with bottom gillnets.

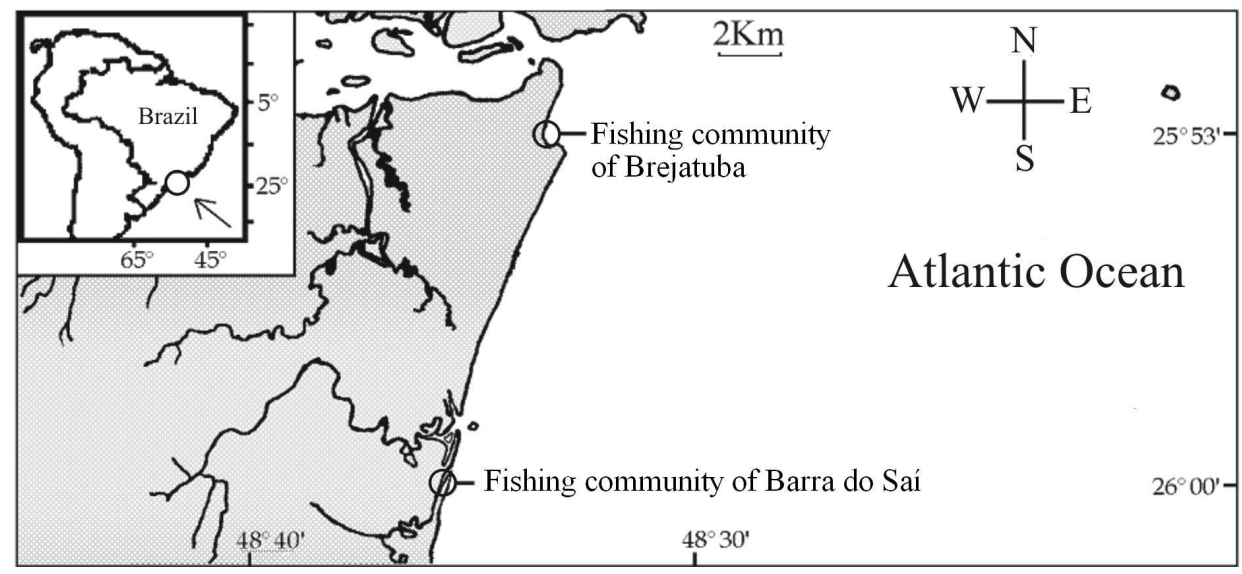

Fig. 1. Fishing communities in Southern Brazil where the specimens of Rhinobatos percellens were obtained for the present study. 
All specimens were weighed (g) using dynamometer, measured (total length - TL $-\mathrm{cm}$ ) and dissected. Stomachs were removed, fixed in $10 \%$ formalin and subsequent analyzed in the laboratory. The food items were separated and identified to the lowest possible taxonomic level. Data analysis comprised Frequency of Occurrence (FO) and the Points method (P) (HYNES, 1950; HYSLOP, 1980). The points were estimated by the area that each item occupies on a grid paper in accordance with Vitule et al. (2008). In order to determine the relative importance of each item, the Alimentary Index (IAi) proposed by Kawakami and Vazzoler (1980) was employed. Food items were grouped in major taxonomic groups in order to analyze the effective importance of the main ecological categories and facilitate the interpretation of results.

The graphical method analysis proposed by Costello (1990) and modified by Amundsen et al. (1996) was used to interpret ecological components of the stomach contents data. This method allows prey importance, feeding strategy, and inter- and intraindividual components of niche breadth to be analyzed by a bidimensional graphic representation.

The trophic level of guitarfish was calculated using the trophic index (TR) (CORTÉS, 1999):

$$
\mathrm{TR}=1+\left(\sum_{j=1}^{n} P_{j} * \mathrm{TR}_{j}\right)
$$

where TR $j$ is the trophic level of each prey taxon $j$ and $\mathrm{P} j$ is the proportion of each prey taxon in the diet of a particular guitarfish species, based on \%IAi values.

A comparative analysis of the diet by season using individual like samples was performed in order to check possible feeding variations. A similarity matrix with the percentage composition values of food items was generated using the Bray-Curtis similarity coefficient. Diet similarity was investigated by the Non-Metric Multidimensional Scaling Analysis (MDS). The analyses were performed on the Primer v6 software (CLARKE; GORLEY, 2006).

\section{Results}

A total of 84 stomachs were processed, of which only three were completely empty and six contained only digested matter, the nine being discarded from analysis. The total length of $R$. percellens individuals varied between 49.1 and 102.0 $\mathrm{cm}$, with an average of $74.2 \mathrm{~cm}(s d=11.4 \mathrm{~cm} ; \mathrm{n}=84)$. Ontogenetic variations in the diet were not evaluated due to the small standard deviation in the sample.

The recorded items were: Teleostei, Crustacea (Decapoda, Anomura, Stomatopoda,
Misydacea and Amphipoda), Polychaeta and Cephalopoda (Table 1). The major food items, regardless of the season, were Decapoda (Dendrobranchiata, Pleocyemata and Brachyura) representing $69 \%$ of the alimentary index and Teleostei representing 22\% (Table 1). The trophic level registered (3.7) is high.

Table 1. Percentage of Frequency of Occurrence (FO), Points (P) and Alimentary Index (IAi) of the items recorded in stomachs of $75 R$. percellens specimens. Trophic level $=3.7$.

\begin{tabular}{lccc}
\hline \hline Food items & FO & P (\%) & IAi (\%) \\
\hline $\begin{array}{l}\text { Decapoda Dendrobranchiata } \\
\text { and/or Pleocyemata }\end{array}$ & 69.14 & 24.70 & 41.94 \\
Decapoda Brachyura & 34.57 & 32.58 & 27.67 \\
Teleostei & 32.10 & 28.29 & 22.30 \\
Unidentified Crustácea & 33.33 & 8.75 & 7.17 \\
Amphipoda & 23.46 & 1.14 & 0.65 \\
Stomatopoda & 2.47 & 2.90 & 0.18 \\
Cephalopoda Teuthoidea & 2.47 & 1.47 & 0.09 \\
Mysidacea & 1.23 & 0.02 & $<0.01$ \\
Anomura & 1.23 & 0.13 & $<0.01$ \\
Polychaeta & 1.23 & 0.02 & $<0.01$ \\
\hline
\end{tabular}

The major prey items (e.g. fishes, shrimps and crabs) were consumed in all seasons, however, different contributions of the items were observed according to the season: Shrimps in Autumn/2002, Fishes in Winter/2002, Shrimps in Spring/2002 and Brachyura in Summer/2003 (Fig. 2).

The feeding strategy of $R$. percellens observed in this study suggested that this species is generalist, with high within-phenotype variation (Fig. $3)$.

\section{DisCUSSION}

The batoid fishes are significant predators in benthic and demersal communities, preying mostly on fishes and invertebrates (MOYLE; CECH-JR., 1988; EBERT et al., 1991; SOARES et al., 1992; CARQUEIJA et al. 1995; PEDERSEN, 1995; WILGA; MOTTA, 1998; MUTO et al., 2002; SHIBUYA et al., 2005; BORNATOWSKI et al., 2006a,b; BASUSTA et al. 2007; MABRAGAÑA; GILBERTO, 2007). The anatomic structures of $R$. percellens (mouth opening relatively larger and body characteristics) permit the guitarfish to crawl and swim with greater velocity and capture highly mobile organisms. For this reason this species preys on fishes, large shrimps and crabs. There is a strong intuitive awareness of the link between the design of organisms and their natural history (WAINWRIGHT; BELLWOOD, 2002). 

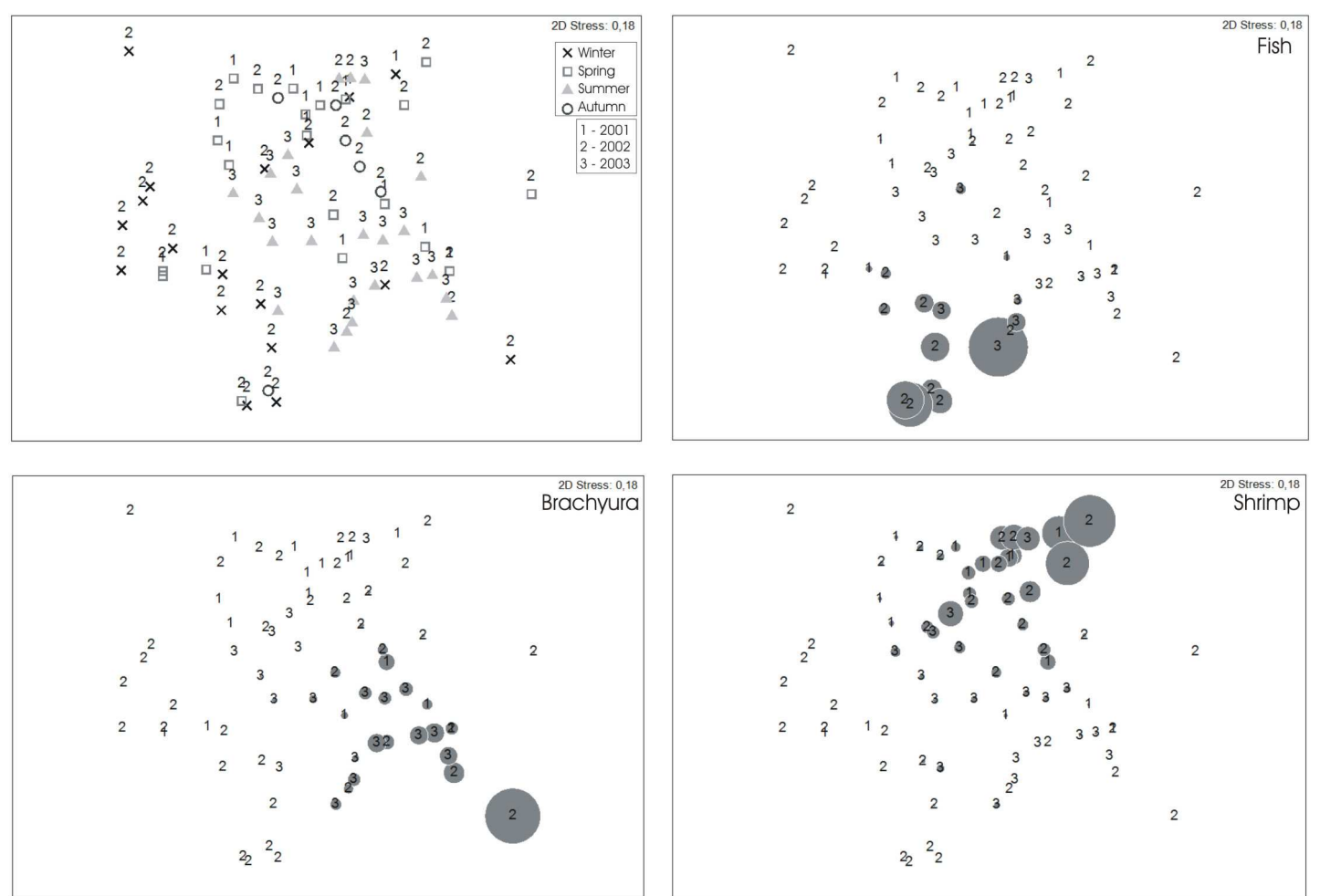

Fig. 2. Graphic representation of the Nonmetric Multidimensional Scaling Analysis (MDS) of the samples (stomachs, $n=75$ ) by the two principal factors (year and season). (a) Ordination of samples by season (represented by symbols) and year (represented by numbers). (b) Contribution of Fish, (c) Brachyura and (d) Shrimp, to the diet of R. percellens (the larger the circle, the greater the percentage contribution.

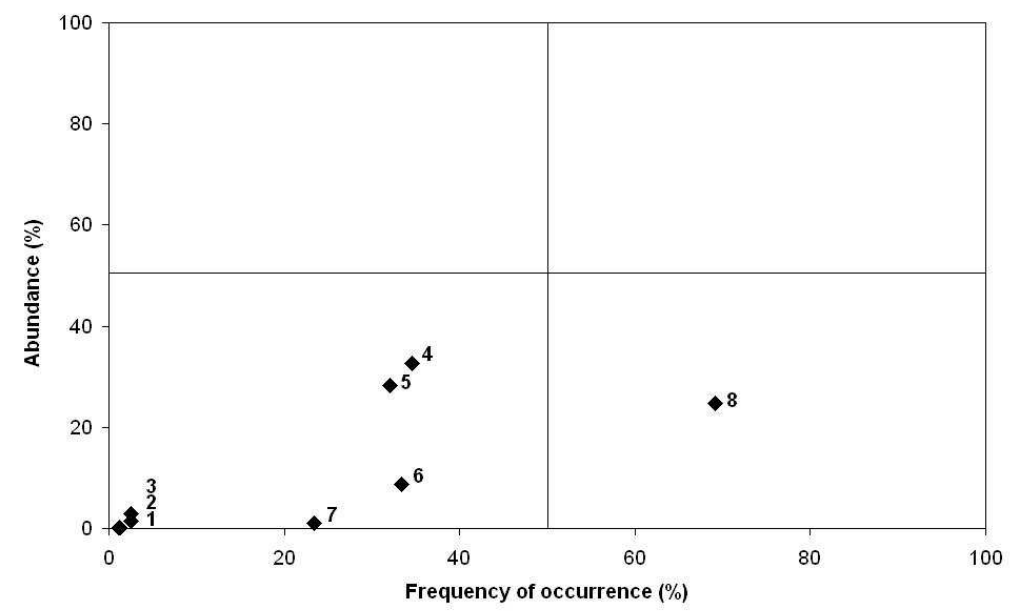

Fig. 3. Feeding strategy diagram. Prey-specific abundance plotted against frequency of occurrence of prey items in the diet of the guitarfish Rhinobatos percellens $(\mathrm{n}=75)$. Prey items: 1. Anomura and Polychaeta, 2. Loliginidae, 3. Stomatopoda, 4. Brachyura, 5. Teleostei, 6. Crustacean remains, 7. Amphipoda, 8. Shrimps. 
Teleostei was the third most important group in the diet of $R$. percellens. Several species of rays have Teleostei as an important component of their diet (SOARES et al., 1992; SILVA; ALMEIDA, 2001; MUTO et al., 2002), including other Rhinobatos species: $R$. horkelii on the Southern Brazilian coast (LESSA, 1982) and $R$. productus in California (TALENT, 1982). Although most Teleostei were not identified to lower taxonomic levels because of the digestion rate, the record of at least one demersal species - Synodus foetens (FIGUEIREDO; MENEZES, 1978) implies that the fish-prey seems to be benthonic. In fact, several food items were found crushed or digested, what is probably related to the rays' feeding behavior, which consists of the suction, manipulation and repeated expulsion of the prey (MOYLE; CECH-JR., 1988; WILGA; MOTTA, 1998).

Polychaeta has been considered the main prey of benthonic batoid fishes (AMARAL; MIGOTTO, 1980; SOARES et al., 1992; MUTO et al. 2002; BORNATOWSKI et al., 2006a,b), including other Rhinobatos spp. (AMARAL; MIGOTO, 1980; HARRIS et al., 1988; ABDEL-AZIZ et al., 1993; SOARES et al., 1992). However, in the present study this item presented low participation in the diet of $R$. percellens, a result also found by Shibuya et al. (2005). Differences in relative item consumption between species have been attributed to the availability of prey items in the environment, to anatomical distinctions among predators, competition between species or digestibility of prey (WEATHERLEY, 1972; MOYLE; CECH-JR., 1982; WOOTTON, 1990; CHAVES; UMBRIA, 2003; ALMEIDA et al., 2000; CHAVES; VENDEL, 1998; MABRAGAÑA; GILBERTO, 2007). The fact that most individuals of $R$. percellens analyzed here were adults cannot be excluded as a factor in the relatively small importance of Polychaeta in the species' diet, as the occurrence of Polychaeta in small individuals has been reported in other fishes (CHAVES; UMBRIA, 2003; ALMEIDA et al., 2000; VENDEL; CHAVES, 1998; BORNATOWSKI et al., 2006a,b; MABRAGAÑA; GILBERTO, 2007; HALUCH et al. 2009). It is also known that various species of fish ingest larger sized preys as they grow (LOWE et al., 1996; SIMPFENDORFER et al. 2001; BORNATOWSKI et al., 2007a; MABRAGAÑA; GILBERTO, 2007; TRELOAR et al., 2008).

Many species of shark frequently consume Cephalopoda, which is usually related to pelagic feeding habits (VASKE-JR.; RINCÓN-FILHO, 1998; CORTÉS, 1999; LIMA et al., 2000; VASKE-JR., 2005; BORNATOWSKI et al., 2007b). The occurrence of the squid Lolliguncula brevis in two stomachs of $R$. percellens indicates that this species can feed on other organisms, evidencing a small degree of opportunism.

As regards the seasonal differences in the feeding habits of guitarfish, during the winter the reduction of Dendrobranchiata and Pleocyemata in the stomach contents may be linked to seasonal fluctuations in the abundance of these organisms, represented mainly by the sea-bob shrimp Xiphopenaeus kroyeri and the white shrimp Litopenaeus schmitti. Both species of shrimps are more abundant in summer and autumn (BRANCO; VERANI, 2006; ROBERT et al. 2007). It is probable that the reduced abundance of shrimp in winter, impels $R$. percellens to eat more Teleostei as an alternative resource. Studies conducted by Muto et al. (2002) on the coast of São Paulo, with Rioraja agassizi and Psammobatis extenta, show similar results.

Rhinobatos percellens is a species commonly caught by artisanal fisheries in southern Brazil (CHAVES et al., 2003; COSTA; CHAVES, 2006; ROBERT, 2008). This species shows a high trophic level and is thus fundamental to and influences the structure and function of marine communities (STEVENS et al., 2000; MOURA et al., 2008; HEITHAUS et al., 2008). The elasmobrachs may be considered keystone species and their removal from coastal ecosystems cold cause a trophic cascading effect within the remaining community (FRID et al., 2007; HEITHAUS et al., 2008; MOURA et al. 2008). Therefore, a constant and effective monitoring of regional fishing activities and studies on the diet composition of elasmobranchs become urgently necessary to provide information on the specific composition, total fishing effort employed in the above-mentioned States and the function of marine communities.

\section{ACKNOWLEDGMENTS}

We wish to thank the fishermen of Barra do Saí and Brejatuba, for their contribution to this study; Dr. Paulo T. C. Chaves for providing space and equipment in the Laboratório de Ictiologia Estuarina at the Universidade Federal do Paraná; Amanda C. de Andrade for the revision of the manuscript; the two anonymous referees; Igor Kintopp Ribeiro for his help with the images; and the Conselho Nacional de Desenvolvimento e Pesquisa $(\mathrm{CNPq})$ for research grants.

\section{REFERENCES}

ABDEL-AZIZ, S. H.; KHALIL, A. N.; ABDEL-MAGUID, S. A. Food and feeding habits of the common guitarfish, Rhinobatos rhinobatos in Egyptian Mediterranean waters. Indian J. Mar. Sci., v. 22, p. 287-290, 1983. 
ALMEIDA, Z. S.; FONSÊCA-GENEVOIS, V.; VASCONSELOS-FILHO, A. L. Alimentação de Achirus lineatus (Teleostei, Pleuronectiforme: Achiridae) em Itapissuma - PE. Bolm Lab. Hidrob., v. 10, p. 79-95, 1997.

AMARAL, A. C. Z.; MIGOTTO, A. E. Importância dos anelídeos poliquetas na alimentação da macrofauna demersal e epibentônica da região de Ubatuba. Bolm Inst. oceanogr., S Paulo, v. 29, n. 2, p. 31- 35, 1980.

AMUNDSEN, P. A.; GABLER, H. M.; STALDVIK, F. L. A new approach to graphical analysis of feeding strategy from stomach contents data - modification of the Costello (1990) method. J. Fish Biol., v. 48, p. 607-614 1996.

BASUSTA, N. S. A.; DEMIRHAN, M. K.; CEKIC, M. Diet of common guitarfish (Rhinobatos rhinobatos 1., 1758) in the Iskenderun Bay (northeastern mediterranean). Rap. Commun. Mer. Medit., v. 38, p. 2007.

BLABER, S. J. M.; BULMAN, C. M. Diets of fishes of the upper continental slope of eastern Tasmania: content, calorific values, dietary overlap and trophic relationships. Mar. Biol., v. 95, p. 345-356. 1987.

BORNATOWSKI, H.; ABILHOA, V.; FREITAS, M. O. Alimentação da raia-viola Zapteryx brevirostris na baía de Ubatuba-Enseada, São Francisco do sul, Santa Catarina, Brasil. Est. Biol.,v. 27, n. 61, p. 31-36, 2006a.

BORNATOWSKI, H.; ABILHOA, V.; FREITAS, M. O. Sobre a alimentação de Narcine brasiliensis na baía de Ubatuba-Enseada, São Francisco do sul, Santa Catarina, Brasil. Est. Biol., v. 28, n. 62, p. 57-60, 2006b.

BORNATOWSKI, H.; ROBERT, M. C.; COSTA, L. Dados sobre a alimentação de jovens de tubarão-tigre, Galeocerdo cuvier (Péron \& Lesueur) (Elasmobranchii, Carcharhinidae), do sul do Brasil. PANAMJAS, v. 2, p. 10-13, 2007a.

BORNATOWSKI, H.; ROBERT, M. C.; COSTA, L.; PINA, J. V. Hábitos alimentares de tubarões martelo jovens, Sphyrna zygaena (Carcharhiniformes: Sphyrnidae), no litoral sul do Brasil. Biota Neotrop., v. 7, n. 1, p. 2007 b.

BRANCO, J. O.; VERANI, J. R. Pesca do camarão setebarbas e sua fauna acompanhante, na Armação do Itapocoroy, Penha, SC. In: BRANCO, J. O.; MARENZI, A. W. C. (Ed.). Bases ecológicas para um desenvolvimento sustentável: estudos de caso em Penha, SC. Itajaí: Editora UNIVALI, p. 153-170, 2006.

BRODEUR, R. D.; LORZ, H. V.; PEARCY, W. G. Food habits and dietary variability of pelagic nekton off Oregon and Washington, 1979-1984. NOAA Tech. Rep. NMFS, v. 57, p. 1-32, 1987.

CADDY, J. F.; SHARP, G. D. . An ecological framework for marine fishery investigations. FAO Fish. tech. Pap., v. 283, p. 1-152, 1986.

CAMHI, M. D.; VALENTI, S. V.; FORDHAM, S. V.; FOWLER, S L.; GIBSON, C. The conservation status of pelagic sharks and rays: Report of the IUCN Shark Specialist Group Pelagic Shark Red List Workshop. Newbury, UK: IUCN Species Survival Commission Shark Specialist Group, 2009. 78 p.

CARQUEIJA, C. R. G.; FILHO, J. J. S.; GOUVEA, E..P.; QUEIROZ, E. L. Decápodos (Crustácea) utilizados na alimentação de Dasyatis guttata (Bloch e Schneider) (Elasmobranchii, Dasyatididae) na área de influência da Estação Ecológica Ilha do Medo, Baía de Todos os
Santos, Bahia, Brasil. Rev. Bras. Zool., v. 12, n. 4, p. 833-838, 1995

CHAVES, P. T. C.; VENDEL, A. L. Feeding habits of Stellifer rastrifer (Perciformes, Sciaenidae) at Guaratuba mangrove, Parana. Brasil. Rev. Bras. Zool., v. 13, n. 3, 669-675, 1998

CHAVES, P. T. C.; UMBRIA, S. C. Changes in diet composition of transitory fishes in coastal systems, estuary and continental shelf. Braz. Arch. Biol. Techn., v. 46, n. 1 , p. 41-46, 2003.

CHAVES, P. T. C.; COVA-GRANDO, G.; CALLUF, C. C. $\mathrm{H}$. Demersal ichthyofauna in a continental shelf region on the south coast of Brazil exposed to shrimp trawl fisheries. Acta biol. Paran., v. 32, n. 1-4, p. 69-82, 2003.

CLARKE, K. R.; GORLEY, R. N. User Manual/Tutorial. PRIMER-E, v. 6, Plymouth, 2006.

COMPAGNO, L. J. V. C. Checklist of living chondrichthyes. In: HAMLETT, W. C. (Ed.) Reproductive biology and phylogeny of chondrichthyes: sharks, batoids, and chimaeras. New Hampshire: Science Publishers, 2005. p. 501-548.

COSTA, L.; CHAVES, P. T. C. Elasmobrânquios capturados pela pesca artesanal na costa sul do Paraná e norte de Santa Catarina, Brasil. (Elasmobranches caught by artisanal fishing in the south coast of Parana State and north coast Santa Catarina State, Brazil). Biota Neotrop., v. 6, n. 3, 2006.

COSTELLO, M. J. Predator feeding strategy and prey importance: a new graphical analysis. J. Fish Biol., v. 36, p. 261-263, 1990.

CORTÉS, E. Standardized diet compositions and trophic levels of sharks. ICES J. mar. Sci., v. 56, p. 707-717, 1999.

EBERT, D. A.; COWLEY, P. D.;COMPAGNO, J. L.V. A preliminary investigation of the feeding ecology of skates (Batoidea: Rajidae) off the west coast of southern Africa. S. Afri. J. mar. Sci, v. 10, p. 71-81, 1991.

FIGUEIREDO, J. L.; MENEZES, N. A. Manual de peixes marinhos do sudeste do Brasil: II. Teleostei (1). São Paulo, Museu de Zoologia da Universidade de São Paulo, 1978

FRID, A.; DILL, L. M.; THORNE, R. E.; BLUNDELL, G. $M$. Inferring prey perception of relative danger in largescale marine systems. Evol. Ecol. Res., v. 9, p. 1-15. 2007.

GERKING, S. D. Feeding ecology of fish. San Diego: Academic Press, 1994. 416 p.

GULLAND, J. A. Fish stock assessment: a manual of basic methods. New York: John Wiley, 1983. 223 p.

HALUCH, C. F.; FREITAS, M. O.; CORRÊA, M. F. M.; ABILHOA, V. Variação sazonal e mudanças ontogênicas na dieta de Menticirrhus americanus (Linnaeus, 1758) (Teleostei, Sciaenidae) na baía de Ubatuba-Enseada, Santa Catarina, Brasil. PANAMJAS, v. 4, n. 3, p. 347-356, 2009

HARRIS, S. A.; BENNETT, B. A.; BRANCH, G. M. An assessment of the role of the sand shark Rhinobatos annulatus as a predator in Langebaan Lagoon. S. Afri. J. mar. Sci., v. 7, p. 153-159, 1988.

HEITHAUS, M. R.; FRID, A.; WIRSING, A. J.; WORM, B. Predicting ecological consequences of marine top predator declines. Trends Ecol. Evolution, v. 23, n. 4, 202-210, 2008. 
HOENIG, J. M.; GRUBER, S. H. Life-history patterns in the elasmobranchs: implications for fisheries management, In: PRATT, JR., H. L., GRUBER, S. H.; TANIUCHI, T. (Ed.). Elasmobranchs as living resources: advances in the biology, ecology, systematics, and the status of the fisheries. U.S. Dept. of Commerce, 1990. NOAA Technical Report NMFS 90. p. 1-16.

HYNES, H. B. N. The food of fresh-water sticklebacks (Gasteronotus aculeatus and Pygosteus pungitius), with a review of methods used in studies of the food of fishes. J. anim. Ecol., v. 19, p. 36-57, 1950.

HYSLOP, E. J. Stomach contents analysis - a review of methods and their application. J. Fish. Biol.,v. 17, p. 411-429, 1980.

KAWAKAMI, E.; VAZZOLER, G. Método gráfico e estimativa de índice alimentar aplicado no estudo de alimentação de peixes. Bolm Inst. oceanogr., S Paulo, 1980 ; v. 29 , n. 2, p. 205-207, 1980

LESSA, R. P. T. Biologie et dynamique des populations de Rhinobatos horkelii du plateau Continental du Rio Grande do Sul. 1982. PhD Thesis. Faculté des Sciences de Brest, Université de Bretagne Occidentale, France, 1982.

LIMA, G. H. L.; DAROS, F. A.; MAZZOLENI, R.; HOSTIM-SILVA, M. Aspectos da alimentação natural do cação-frango Rhizoprionodon lalandii (Valenciennes, 1841) (Elasmobranchii, Carcharhinidae) no município de Barra Velha, Santa Catarina. Notas téc. FACIMAR, v.4, p. 91-96, 2000.

LOWE, C. J.; WETHERBEE, B. M.; CROW, G. L TESTER, A. L. Ontogenetic dietary shifts and feeding behaviour of the tiger shark, Galeocerdo cuvier, in Hawaiian waters. Environ. Biol. Fishes, v. 47, p. $203-$ 211, 1996.

MABRAGAÑA, E.; GIBERTO, D. A. Feeding ecology and abundance of two sympatric skates, the shortfin sand skate Psammobatis normani McEachran, and the smallthorn sand skate $P$. rudis Günther (Chondrichthyes, Rajidae), in the southwest Atlantic. ICES J. mar. Sci., v. 64, p. 1017-1027, 2007.

MARTINS, R. R.; SCHWINGEL, P. R. Variação espaçotemporal da CPUE para o gênero Rhinobatos (Rajiformes, Rhinobatidae) na costa sudeste e sul do Brasil. Notas téc. FACIMAR, v. 7:, p. 119-129, 2003.

McEACHRAN, J. D.; CARVALHO, M. R. Batoids. In: CARPENTER, K.E.; NIEM, V.H. (Ed.). The living marine resources of the Western Central Pacific. Vol. 3. Batoid fishes, chimaeras and bony fishes, Part 1. Elopidae to Linophrynidae. Rome: FAO species identification guide for fishery purposes, 1999. p. $507-$ 589

MENEZES, N. A.; BUCKUP, P. A.; FIGUEIREDO, J. L.; MOURA, R. . Catálogo das espécies de peixes marinhos do Brasil. São Paulo: Museu de Zoologia da Universidade de São Paulo, 2003. 160 p.

MOYLE, P. B.; CECH-JR., J. J. Fishes: an introduction to ichthyology. Englewood Cliffs: Prentice-Hall, 1982. 726 p.

MOURA, T.; FIGUEIREDO, I.; FARIAS, I.; SERRAPEREIRA, B.; NEVES, A.; BORGES, M. F.; GORDO, L.S. Ontogenetic dietary shift and feeding strategy of Raja undulata Lacepède, 1802 (Chondrichthyes: Rajidae) on the Portuguese continental shelf. Sci. Mar. v. 72 , n. 2 , p. $311-318,2008$.
MUSICK, J. A. Introduction. In: FOWLER, S. .L; CAVANAGH, R .D.; CAMHI, M.; BURGESS, G. H.; CAILLIET, G. M.; FORDHAM, S. V.; SIMPFENDORFER, C. A.; MUSICK, J. A. (Ed.). Sharks, Rays and Chimaeras: The Status of the Chondrichthyan Fishes IUCN/SSC Shark Specialist Group. Gland, Switzerland; Cambridge, UK: IUCN, 2005. $461 \mathrm{p}$.

MUTO, E. Y.; SOARES, L. S. H.; GOITEIN, R. Food resource utilization of the skates Rioraja agassizi (müller and henle, 1841) and Psammobatis extenta (garman, 1913) on the continental shelf off Ubatuba, south-eastern Brazil. Rev. Bras. Biol., v. 61, n. 2, p. 217-238, 2002.

PAULY, D. Fish population dynamics in tropical waters: a manual for use with programmable calculators. Manila: ICLARM, 1984. 325 p.

PEDERSEN, S. A. Feeding habits of starry ray (Raja radiata) in the West Greenland waters. ICES J. mar. Sci., v. 52, p. 43-53, 1995.

POWER, M. E. Estimating impacts of a dominant detritivore in a neotropical stream. Trends Ecol. Evolution, v. 12, n. 2, p. 47-48, 1997.

ROBERT, M. C. Variações nos procedimentos de pesca associadas às flutuações sazonais na disponibilidade do recurso ictiofaunístico costeiro na região limítrofe Paraná/Santa Catarina: um estudo de caso na comunidade de Barra do Saí (Itapoá, SC). PhD Thesis, 2008. Universidade Federal do Paraná, Curitiba, 2008.

ROBERT, R.; BORZONE, C. A.; NATIVIDADE, C. D. Os camarões da fauna acompanhante na pesca dirigida ao camarão-sete-barbas (Xiphopenaeus kroyeri) no litoral do Paraná. Bolm Inst. Pesca, v. 33, n. 2, p. 237-246, 2007.

SHIBUYA, A.; ROSA, R. S.; GADIG, O. B. F. Note on the diet of the guitarfish Rhinobatos percellens (Walbaum, 1792) (Elasmobranchii: Rhinobatidae) from the coast of Paraíba, Brazil. Acta biol. Leopol., v. 27, n. 1, p. 63-64, 2005.

SILVA, C. M. L.; ALMEIDA, Z. S. Alimentação de Rhizoprionodon porosus (elasmobranchii: carcharhinidae) da costa do Maranhão, Brasil. Bolm Inst. Pesca, v. 27, n. 2, p. 201-207, 2001.

SIMPFENDORFER, C.; GOODREID, A. B.; McAULEY, R. B. Size, sex and geographic variation in the diet of the tiger sharks, Galeocerdo cuvier, from Western Australian waters. Environ. Biol. Fish., v. 61, p. 37-46, 2001

SOARES, L.S.H.; ROSSI-WONGTSCHOWSKI, C. L. D. B.; ÁLVARES, L. M. C.; MUTO, E. Y.; GASALLA, M. L. A. Grupos tróficos de peixes demersais da plataforma continental interna de Ubatuba, Brasil. I. Chondrichthyes. Bolm Inst. oceanogr., S Paulo, v.., 40, n.1/2, p. 79-85, 1992.

STEVENS, J. N.; BONFIL, R.; DULVY, N.; WALKER, P. The effects of fishing on sharks, skates, rays and chimaeras (chondrichthyans) and the implications for marine ecosystems. ICES J. mar. Sci.,v. 57:, p. 476474, 2000.

TALENT, L. G. Food habits of the gray smoothhound, Mustelus californicus, the brown smoothhound, Mustelus henlei, the shovelnose guitarfish, Rhinobatos productus and the bat ray, Myliobatis californica, in Elkhorn Slough, California. Calif. Fish Game, v. 68, n. 4, p. 224234, 1982. 
TRELOAR, M.; LAURENSON, L. J. B.; STEVENS, J. D. Dietary comparisons of six skate species (Rajidae) in southeastern Australian waters. Environ. Biol. Fish., v. 80, p. 181-196, 2008

VASKE-JR., T.; RÍNCON-FILHO, G. Conteúdo estomacal dos tubarões azul (Prionace glauca) e anequim (Isurus oxyrinchus) em águas oceânicas no sul do Brasil. Rev. Bras. Biol., v. 5, n. 3, p. 445-452 Bras. Biol., v. 58, n. 3, p. 445-452, 1998. 3): 445-452. 1998.

VASKE-JR. T. Cefalópodes oceânicos da zona econômica exclusiva do nordeste do Brasil. Bol. Inst. Pesca, 31(2): 137 - 146. 2005

VENDEL, A. L.; CHAVES, P. T. C. Alimentação de Bairdiella ronchus (Perciformes, Sciaenidae) na Baía de Guaratuba, Paraná, Brasil. Rev. Bras. Zool., v. 15, n. 2, p. 297-305, 1998

VITULE, J. R. S.; BRAGA, M. R.; ARANHA, J. M. R. Ontogenetic, spatial and temporal variations in the feeding ecology of Deuterodon langei Travassos, 1957 (Teleostei: Characidae) in a Neotropical stream from the Atlantic rainforest, southern Brazil. Neotrop. Ichthyol., v. 6, n. 2, p. 211-222, 2008

VOOREN, C. M.; LESSA, R. P.; KLIPPEL, S. Biologia e status de conservação da viola Rhinobatos horkelli. In: VOOREN, C. M.; KLIPPEL, S. (Ed.). Ações para conservação de tubarões e raias no sul do Brasil. Porto Alegre: Igaré, 2005. Cap. 3, p. 33-56.
WAINWRIGHT, P. C.; BELLWOOD, D. R. Ecomorphology of feeding in coral reef fishes. In: SALE, P. F. (Ed.). Coral reef fishes: dynamics and diversity in a complex ecosystem. San Diego: Academic Press, 2002. p. 33-55.

WEATHERLEY, A. H. Growth and ecology of fish populations.London: Academic Press, 1972. $293 \mathrm{p}$

WILGA, C. D.; MOTTA, P. J. Feeding mechanism of the atlantic guitarfish Rhinobatos lentiginosus: modulation of kinematic and motor activity. J. expl Biol., v. 201, p. 3167-3184, 1998.

WINEMILLER, K. O.; AGOSTINHO, A. A.; CARAMASCHI, E. P. Fish ecology in tropical streams. In: DUDGEON, D. (Ed.). Tropical stream Ecology. San Diego: Elsevier/Academic Press, 2008. p.107-146.

WOOTTON, R.J. Ecology of teleost fishes. London: Chapman and Hall, 1990. 404 p.

(Manuscript received 20 March 2009; revised 05 May 2009; accepted 13 July 2009) 